\title{
RISIKO PRODUKSI DAN PEMASARAN TERHADAP PENDAPATAN PETANI MANGGA: KELOMPOK MANA YANG PALING BERISIKO
}

\author{
ELLY RASMIKAYATI ${ }^{1,2}$, LIES SULISTYOWATI ${ }^{1}$, BOBBY RACHMAT \\ SAEFUDIN $^{2}$ \\ ${ }^{1}$ Fakultas Pertanian, Universitas Padjadjaran \\ ${ }^{2}$ Pusat Riset Pangan Berkelanjutan DRPM UNPAD \\ Email: e.rasmikayati@unpad.ac.id; elly.agri@yahoo.co.id
}

\begin{abstract}
ABSTRAK
Permintaan konsumen terhadap buah, khususnya mangga semakin besar, seiring dengan meningkatnya pendapatan dan kesadaran konsumen akan pentingnya mengkonsumsi buah sebagai salah satu penjaga kesehatan. Konsumen sekarang ini menghendaki mangga selalu tersedia di pasar disertai dengan kualitas yang terjaga prima. Untuk memenuhi tuntutan konsumen tersebut, petani tidak bisa berperilaku seadanya dalam menangani mangga, tetapi perlu lebih bersikap profesional terutama dalam usahatani dan pemasaran mangganya. Berdasarkan hal tersebut, tujuan dari penelitian ini adalah untuk mendeskipsikan dan mengkaji dampak dari risiko produksi dan pemasaran terhadap pendapatan petani mangga serta mengidentifikasi kelompok mana yang paling berisiko. Penelitian ini dilakukan dengan metode survey. Petani mangga di Kabupaten Cirebon dan Majalengka diambil sebanyak 240 orang dengan menggunakan teknik Multi Stage Cluster Random Sampling. Hasil penelitian menunjukkan bahwa faktor-faktor risiko produksi dan risiko pemasaran seperti risiko jumlah pohon, risiko biaya pupuk kandang, risiko biaya pestisida dan risiko harga jual mangga berpengaruh signifikan terhadap pendapatan petani. Sementara itu, terdapat perbedaan perilaku petani dalam produksi dan pemasaran mangganya jika petani dibagi ke dalam tiga kelompok, berdasarkan jumlah pohon yang dikuasai, yaitu petani yang jumlah pohonnya terbatas, cukup dan banyak. Diantaranya perbedaan tersebut adalah dalam hal rata-rata harga jual mangga per kilogram. Fakta selanjutnya, petani yang jumlah pohonnya terbatas dibanding dengan petani dari kelompok lainnya, kurang berani mengambil risiko produksi, tetapi mereka lebih berani mengambil risiko pemasaran.
\end{abstract}

Kata kunci: Permintaan mangga, risiko produksi, risiko pemasaran, pendapatan usahatani, perilaku petani

\section{PENDAHULUAN}

Mangga merupakan buah unggulan nasional yang sangat diminati masyarakat, juga sangat berpotensi untuk memberikan peningkatan kesejahteraan kepada keluarga petani karena memiliki nilai ekonomis yang tinggi (Natawidjaja, 2013). Untuk itu, Provinsi Jawa Barat sudah bertekad menjadikan mangga sebagai komoditas yang diprioritaskan pengembangannya, dengan kabupaten sentra mangga yang potensial sebagai wilayah pengembangan adalah Cirebon, Majalengka, dan Indramayu (Sulistyowati dan Rasmikayati, 2014).

Permintaan konsumen terhadap 
Risiko Produksi dan Pemasaran Terhadap Pendapatan Petani Mangga:

Kelompok Mana yang Paling Berisiko

ELLY RASMIKAYATI ${ }^{2}$, LIES SULISTYOWATI, BOBBY RACHMAT SAEFUDIN

buah, khususnya mangga semakin besar, seiring dengan meningkatnya pendapatan dan kesadaran konsumen akan pentingnya mengkonsumsi buah sebagai salah satu penjaga kesehatan. Konsumen sekarang ini menghendaki mangga selalu tersedia di pasar disertai dengan kualitas yang terjaga prima. Untuk menghasilkan produksi mangga yang berkualitas serta berkelanjutan dibutuhkan pengelolaan yang intensif dengan penerapan teknologi yang tepat. Untuk memenuhi tuntutan konsumen tersebut, petani tidak bisa berperilaku seadanya dalam menangani mangga, tetapi perlu lebih bersikap profesional terutama dalam usahatani dan pemasaran mangganya.

Masalahnya, walau teknologi dan cara pembudidayaan mangga yang intensif telah diperkenalkan oleh Dirjen Hortikultura dan pihak-pihak lainnya, petani memiliki persepsi, dorongan dan motivasi yang berbeda sehingga penggunaan teknologi dan praktek budidaya yang dianjurkan keberhasilannya masih sangat terbatas. Hal ini merupakan risiko yang dihadapi oleh petani mengga.

Ellis (1993) mengemukakan risiko adalah suatu kejadian dimana hasil dan peluangnya bisa ditentukan. Selanjutnya dikatakan, risiko merupakan deskripsi karakter dan lingkungan ekonomi yang dihadapi oleh petani, di mana lingkungan tersebut mengandung beragam ketidakpastian yang direspon oleh petani berdasarkan kepercayaan subyektifnya. Secara normal tidak ada satu orang pun yang mau masuk ke lingkungan yang penuh dengan risiko tanpa mengharapkan perolehan (return) yang lebih besar.

Saptana, dkk. (2010) telah mengkaji risiko pada usahatani cabai merah dan perilaku petani cabai dalam menghadapi risiko tersebut. Begitu pula hal nya pada usahatani mangga. Risiko yang dihadapi petani terangkum dalam aspek produksi dan pemasaran dimana pada akhirnya dapat berimbas pada pendapatan petani. Berdasarkan hal tersebut, tujuan dari penelitian ini adalah untuk mendeskipsikan dan mengkaji dampak dari risiko produksi dan pemasaran terhadap pendapatan petani mangga serta mengidentifikasi kelompok mana yang paling berisiko.

\section{TINJAUAN PUSTAKA}

\section{Komoditas Unggulan Jawa Barat}

Komoditas unggulan Jawa Barat menurut Dinas Pertanian Tanaman Pangan Provinsi Jawa Barat (2014) antara lain mangga, alpukat, belimbing, duku, durian, jambu biji, jambu air, jeruk, manggis, 
Jurnal Pemikiran Masyarakat Ilmiah Berwawasan Agribisnis. 2017. 3(2): 105-116

nangka, nenas, pepaya, pisang, rambutan, salak, sawo, markisa, sirsak, sukun, melinjo dan pete. Di antara komoditas tersebut buah mangga, durian, manggis, jeruk dan rambutan merupakan komoditas yang masuk kedalam unggulan di Indonesia.

Salah satu komoditas hortikultura dari sektor buah-buahan yaitu buah mangga yang masuk ke dalam komoditas unggulan merupakan salah satu penghasil devisa negara karena mampu menembus pasar internasional. Mangga merupakan komoditas unggulan Jawa Barat karena memiliki keunggulan komparatif maupun kompetitif dengan jumlah permintaan akan komoditas mangga yang mengalami peningkatan baik dalam negeri maupun luar negeri. Mangga merupakan komoditas yang dapat diharapkan sebagai andalan sumber pendapatan petani dan juga sebagai sumber gizi masyarakat, terutama sebagai sumber vitamin A dan C.

Jawa Barat merupakan daerah yang menghasilkan produksi mangga tertinggi kedua setelah Jawa Timur. Akan tetapi produktivitasnya lebih tinggi dibandingkan Jawa Timur dengan jumlah produksi pada tahun 2011 sebesar 357.188 ton dan produktivitas 12,66 ton/ha.

Pada saat musim panen (on season), harga mangga di tingkat petani berkisar
Rp 7.000,- sampai dengan Rp 20.000,-. Sedangkan pada saat off season harga mangga di tingkat petani berkisar $\mathrm{Rp}$ 10.000,- sampai dengan Rp 30.000,-.

Komoditas mangga yang banyak digemari masyarakat dan memiliki nilai ekonomis yang cukup tinggi adalah mangga arumanis, dermayu dan gedong gincu. Direktorat Jendral Hortikultura (2008) menyebutkan bahwa budidaya modern dan teknologi pembungaan (off season) merupakan teknologi yang dapat mempercepat tanaman mengeluarkan bunga untuk bakal buah sebelum waktu musimnya yang telah diperkenalkan sejak 15 tahun yang lalu. Dengan adanya teknologi tersebut diharapkan mampu untuk memenuhi permintaan konsumen akan buah segar mangga yang terus mengalami peningkatan.

\section{Konsep Risiko}

Risiko dan ketidakpastian pada awalnya digunakan secara bersama-sama baik dalam jurnal maupun dalam beberapa tulisan lainnya. Henderson dan Quant (1980), Varian (1992), serta Samuelson dan Nordhaus (1993) menggunakan istilah ketidakpastian (uncertainty) terkait dengan peluang (probability). Knight (1921) adalah orang yang pertama-tama mampu memisahkan dengan jelas antara 
Risiko Produksi dan Pemasaran Terhadap Pendapatan Petani Mangga:

Kelompok Mana yang Paling Berisiko

ELLY RASMIKAYATI ${ }^{2}$, LIES SULISTYOWATI, BOBBY RACHMAT SAEFUDIN

istilah risiko dan ketidakpastian.

Debertin (1986) mengemukakan

Dikemukakan bahwa sesuatu peristiwa lingkungan disebut ketidakpastian apabila hasil dari kejadian akhir yang kemungkinan terjadinya (possible outcome), dan kebolehjadian (possibility) untuk masing-masing peristiwa itu tidak diketahui. Sedangkan, dalam lingkungan yang mengandung risiko, baik keluaran (outcome) maupun kebolehjadian (possibility) terjadinya peristiwa itu dapat diketahui.

Vlek dan Stallen (1981) mendaftar paling tidak ada enam definisi mengenai risiko, yaitu: (1) Risiko adalah peluang terjadinya kerugian; (2) Risiko adalah ukuran dari kemungkinan terjadinya kerugian; (3) Risiko adalah sebuah fungsi, sebagian besar produk dari peluang dan ukuran kerugian; (4) Risiko adalah sama dengan keragaman dari distribusi peluang pada semua konsekuensi dari serangkaian aksi berisiko; (5) Risiko adalah semivarian dari distribusi pada semua konsekuensi, hanya mengambil alih konsekuensi yang bersifat negatif, dan berkenaan dengan beberapa nilai referensi yang diadopsi; dan (6) Risiko adalah sebuah pembobotan kombinasi linier dari varian dan distribusi nilai yang diharapkan dari semua konsekuensi-konsekuensi kemungkinan. bahwa risiko sebagai suatu kejadian di mana hasil dari kejadian dan peluang terjadinya bisa diketahui secara pasti. Robinson dan Barry (1987) menyatakan bahwa jika peluang suatu kejadian dapat diketahui oleh pembuat keputusan yang didasarkan pada pengalaman, maka hal tersebut menunjukkan konsep risiko. Selanjutnya dikatakan bahwa dalam menganalisis risiko didasarkan pada teori pengambilan keputusan dengan berdasarkan pada konsep kepuasan yang diharapkan (expected utility). Dalam kaitannya dengan expected utility sangat erat hubungannya dengan peluang (probability). Kepuasan (utility) sangat sulit diukur sehingga umumnya didekati dengan pengukuran pendapatan (return). Indikator adanya risiko ditunjukkan oleh adanya variasi atau fluktuasi dari return dengan asumsi faktor-faktor tertentu bersifat tetap.

Menurut Ellis (1988), peluang berarti frekuensi yang diharapkan terjadi dari sebuah kejadian (jumlah seluruh kemungkinannya adalah satu). Dengan demikian risiko merupakan suatu hal yang obyektif dengan asumsi informasi tersedia cukup. Dalam prakteknya informasi tidak semata-mata menunjuk pada pengetahuan seseorang atas kejadian tertentu melainkan 
Jurnal Pemikiran Masyarakat Ilmiah Berwawasan Agribisnis. 2017. 3(2): 105-116

lebih pada derajat personal pengambil keputusan. Dengan kata lain, seberapa besar kepercayaan orang tersebut pada setiap peluang yang mungkin terjadi, hingga batas ini risiko bergeser dari sudut pandang obyektif menjadi subyektif.

Ellis (1988) mengemukakan ketidakpastian adalah suatu kejadian dimana hasil dan peluangnya tidak bisa ditentukan. Jadi ketidakpastian tidak berkaitan dengan peluang-peluang. Selanjutnya dikatakan, ketidakpastian merupakan deskripsi karakter dan lingkungan ekonomi yang dihadapi oleh petani, dimana lingkungan tersebut mengandung beragam ketidakpastian yang direspon oleh petani berdasarkan kepercayaan subyektifnya. Secara normal tidak ada satu orangpun yang mau masuk ke lingkungan yang penuh dengan risiko tanpa mengharapkan perolehan (return) yang lebih besar.

\section{METODE PENELITIAN}

\section{Design Penelitian}

Penelitian ini dilakukan dengan metode survey. Petani mangga di
Kabupaten Cirebon dan Majalengka diambil sebanyak 240 orang dengan menggunakan teknik Multi Stage Cluster Random Sampling. Tahapannya, pertamatama menentukan 2 kabupaten yang merupakan produsen mangga terbesar yakni Cirebon dan Majalengka. Kemudian, dari masing-masing kabupaten terpilih 1 kecamatan yakni Kecamatan Sedong di Kabupaten Cirebon, dan Kecamatan Panyingkiran di Kabupaten Majalengka. Selanjutnya, dari tiap kecamatan, diambil dua desa sentra mangga. Masing-masing desa diambil responden petani secara random 60 responden, sehingga jumlah total responden petani mangga 240 orang.

\section{Metode Analisis}

Model Estimasi

Pengaruh faktor-faktor produksi dan pemasaran serta faktor-faktor risiko produksi dan risiko pemasaran terhadap pendapatan petani mangga akan diestimasi menggunakan model persamaan regresi majemuk sebagai berikut:

$$
Y_{i}=a+\sum_{j=1}^{12} b_{j} X_{j}+b_{13} d_{1}+b_{14} d_{2}+b_{15} d_{3}+\sum_{j=1}^{8} c_{j} Z_{j}+u
$$

Keterangan:

$Y_{i}=$ Pendapatan usahatani petani ke- $i$ (Rupiah/tahun)

$X_{1}=$ Produktivitas (kg/pohon) 
Risiko Produksi dan Pemasaran Terhadap Pendapatan Petani Mangga:

Kelompok Mana yang Paling Berisiko

ELLY RASMIKAYATI ${ }^{2}$, LIES SULISTYOWATI, BOBBY RACHMAT SAEFUDIN

$X_{2}=$ : Luas lahan (hektar)

$X_{3}=$ Jumlah pohon

$X_{4}=$ Biaya bibit (Rupiah)

$X_{5}=$ Biaya pupuk NPK (Rupiah)

$X_{6}=$ Biaya pupuk ZA/KNO (Rupiah)

$X_{7}=$ Biaya pupuk kandang (Rupiah)

$X_{8}=$ Biaya ZPT (Rupiah)

$X_{9}=$ Biaya pestisida (Rupiah)

$X_{10}=$ Biaya tetap (Rupiah)

$X_{11}=$ Biaya tenaga kerja (Rupiah)

$X_{12}=$ Harga jual mangga $($ Rupiah $/ \mathrm{kg})$

$d_{1}=$ Dummy sistem penjualan $(0=$ abresan; $1=$ sortir $)$

$d_{2}=$ Dummy pasar $(0=$ pasar tradisional; $1=$ pasar modern/ekspor $)$

$d_{3}=$ : Dummy jangkauan pasar $(0=$ desa hingga kabupaten; $1=$ luar kabupaten $)$

$Z_{1}=$ : Risiko luas lahan (hektar)

$Z_{2}=$ : Risiko jumlah pohon

$Z_{3}=$ : Risiko biaya pupuk NPK (Rupiah)

$Z_{4}=$ Risiko biaya pupuk ZA/KNO (Rupiah)

$Z_{5}=$ : Risiko biaya pupuk kandang (Rupiah)

$Z_{6}=$ Risiko biaya ZPT (Rupiah)

$Z_{7}=$ Risiko biaya pestisida (Rupiah)

$Z_{8}=$ Risiko harga jual mangga (Rupiah)

$a=$ Konstanta

$b_{j}, c_{j}=$ Koefisien regresi

$u=$ Kesalahan (disturbance term)

Dalam model estimasi ini, risiko adalah selisih dari nilai optimal dengan nilai aktualnya (Ruminta, 2011). Sebelum melakukan estimasi, terlebih dahulu harus dipastikan bahwa tidak ada asumsi klasik yang dilanggar pada model persamaan regresi fungsi pendapatan tersebut. Kemudian setelah dilakukan estimasi regresi, untuk mengukur ketepatan fungsi regresi dalam menaksir nilai aktual dapat lakukan dengan melihat Goodness of Fit-nya. Untuk melakukan semua jenis pengujian tersebut digunakan alat bantu berupa perangkat lunak SPSS for Windows 17.

\section{Analisis Perilaku Petani dalam Produksi dan Pemasaran Mangga}

Petani mangga dalam cakupan penelitian ini dibagi menjadi tiga kelompok berdasarkan jumlah pohon yang dikuasainya, yaitu petani yang jumlah pohonnya terbatas, cukup dan banyak. Petani yang jumlah pohonnya terbatas adalah petani yang menguasai paling banyak 60 pohon mangga, sedangkan petani yang jumlah pohonnya cukup adalah petani yang menguasai lebih dari 60 pohon sampai 150 pohon mangga, dan petani yang jumlah 
pohonnya banyak adalah yang menguasai lebih dari 150 pohon mangga. Perilaku ketiga kelompok petani tersebut dapat dilihat dari produktivitas per pohon, biaya usahatani per pohon, harga jual mangga per kilogram dan penerimaan petani per pohon. Kemudian alat analisis yang digunakan adalah uji beda rata-rata 3 populasi independen menggunakan alat bantu Microsoft Excel 2007.

\section{Analisis Perilaku Petani Mangga dalam Menghadapi Risiko Produksi dan Risiko Pemasaran}

Petani mangga dibagi 2 kelompok yaitu petani yang jumlah pohonnya terbatas ( $\$ 60$ pohon) dan petani lainnya yang jumlah pohonnya di atas 60 pohon. Kedua kelompok tersebut akan dibandingkan perilakunya dalam hal produktivitas per pohon, biaya usahatani per pohon, harga jual mangga per kilogram dan penerimaan petani per pohon menggunakan uji beda rata-rata 2 populasi independen menggunakan alat bantu Microsoft Excel 2007. Kesimpulan akhir yang akan diperoleh adalah kelompok mana yang lebih berani mengambil risiko produksi dan pemasaran serta bagaimana dampak dari perilaku petani tersebut.

\section{HASIL DAN PEMBAHASAN}

Faktor-faktor yang Menjadi Determinan Terhadap Pendapatan Petani Mangga

Berikut adalah hasil estimasi faktor-faktor yang menjadi determinan terhadap pendapatan petani mangga setelah memenuhi asumsi-asumsi klasik dan goodness of fit.

\section{Faktor-faktor Biaya Produksi dan Pemasaran}

Hasil estimasi seperti disajikan pada Tabel 1 menunjukkan bahwa faktorfaktor biaya produksi dan pemasaran yang mempengaruhi pendapatan petani mangga adalah biaya bibit mangga, biaya pupuk ZA/KNO, biaya pupuk kandang, biaya pestisida, biaya tetap, biaya tenaga kerja, dan dummy sistem penjualan.

Biaya bibit dan biaya pupuk ZA/KNO berpengaruh positif terhadap pendapatan petani mangga. Artinya, semakin besar biaya yang dikeluarkan untuk kedua variabel ini pada akhirnya akan menambah pendapatan petani mangga. Hal ini dikarenakan semakin besar biaya bibit akan berbanding lurus dengan jumlah pohon (kuantitias bibit) dan juga kualitas bibit itu sendiri sehingga pada akhirnya akan menambah produksi mangga dan menaikkan 
Risiko Produksi dan Pemasaran Terhadap Pendapatan Petani Mangga:

Kelompok Mana yang Paling Berisiko

ELLY RASMIKAYATI ${ }^{2}$, LIES SULISTYOWATI, BOBBY RACHMAT SAEFUDIN

pendapatan petani mangga. sedangkan

pupuk ZA/KNO merupakan salah satu

pupuk utama yang diperlukan untuk

meningkatkan kualitas buah mangga

terutama dalam menambah rasa manis pada buah mangga sehingga pada akhirnya dapat menaikkan harga jual dari mangga itu sendiri.

Tabel 1. Koefisien Regresi serta Nilai Keberartiannya

\begin{tabular}{lrrr}
\hline \multicolumn{1}{c}{ Variabel } & \multicolumn{1}{c}{ Koefisien } & t-statistik & taraf nyata \\
\hline (Constant) & 2433293252,85 & 6,635 & 0,000 \\
Produktivitas & 441374,96 & 10,634 & 0,000 \\
Biaya_bibit & 13,35 & 1,707 & 0,089 \\
Biaya_NPK & 2,82 & 1,389 & 0,166 \\
BiayaZA_KNO & 53,76 & 2,518 & 0,013 \\
Biaya_PKandang & $-0,64$ & $-3,051$ & 0,003 \\
BiayaZPT & $-2,76$ & $-0,924$ & 0,356 \\
BiayaPestisida & 0,00 & $-3,445$ & 0,001 \\
Biaya_Tetap & $-0,81$ & $-6,064$ & 0,000 \\
BiayaTenagakerja & $-0,78$ & $-2,471$ & 0,014 \\
DummySistemjual & $-16272561,62$ & $-1,786$ & 0,076 \\
DummyTujuanpasar & $-11808889,93$ & $-1,515$ & 0,131 \\
DummyJangkauanpasar & 16328952,54 & 1437 & 0,152 \\
RisikoLuaslahan & 2228932,90 & 0.263 & 0,793 \\
RisikoJumlahpohon & $-270181,25$ & -2.614 & 0,010 \\
RisikoBiayaNPK & $-1812,73$ & -0.170 & 0,865 \\
RisikoBiayaZA_KNO & 13278,92 & 0.353 & 0,724 \\
RisikoBiayaPKandang & $-4533,71$ & -5.017 & 0,000 \\
RisikoBiayaZPT & $-1573,37$ & -1.026 & 0,306 \\
RisikoBiayaPestisida & $-170,09$ & -3.676 & 0,000 \\
RisikoHargaJual & $-3344,66$ & $-2,539$ & 0,012 \\
\hline Sumber: Dara & & &
\end{tabular}

Sumber: Data Primer, 2014 (diolah)

Sementara itu, biaya pupuk kandang, biaya pestisida, biaya tetap dan biaya tenaga kerja berpengaruh negatif terhadap pendapatan petani mangga. Sehingga untuk menambah pendapatannya, petani mangga perlu untuk mengurangi biaya yang mereka keluarkan untuk variabel-variabel tersebut. Variabel dummy sistem penjualan berpengaruh negatif, sehingga dapat disimpulkan bahwa sistem penjualan mangga secara tebasan lebih baik dari pada sistem penjualan grading dalam hal besaran pendapatan yang didapat oleh petani.

\section{Faktor-Faktor Risiko Produksi dan Pemasaran}

Berdasarkan hasil estimasi seperti disajikan pada Tabel 1 menunjukkan 
Jurnal Pemikiran Masyarakat Ilmiah Berwawasan Agribisnis. 2017. 3(2): 105-116

bahwa faktor-faktor risiko produksi dan pemasaran yang mempengaruhi pendapatan petani mangga adalah risiko jumlah pohon, risiko biaya pupuk kandang, risiko biaya pestisida dan risiko harga jual mangga.

Variabel risiko produksi seperti risiko jumlah pohon, risiko biaya pupuk kandang dan risiko biaya pestisida serta variabel risiko pemasaran yaitu risiko harga jual mangga berpengaruh negatif terhadap pendapatan petani mangga. Artinya bahwa semakin besar selisih antara nilai ideal dengan nilai aktual pada setiap variabel akan menurunkan pendapatan.

\section{Perilaku Petani Dalam Produksi Dan Pemasaran Mangga}

Hasil analisis seperti tersaji pada Tabel 2 menunjukkan bahwa rata-rata produkivitas per pohon pada petani yang jumlah pohonnya terbatas adalah $138 \mathrm{~kg}$ per pohon, petani yang jumlah pohonnya cukup adalah $152 \mathrm{~kg}$ per pohon dan petani yang jumlah pohonnya banyak adalah $136 \mathrm{~kg}$ per pohon. Berdasarkan hasil uji beda untuk ketiga kelompok tersebut didapatkan hasil bahwa tidak terdapat perbedaan yang signifikan untuk rata-rata produktivitas mangga per pohon pada ketiga kelompok tersebut.

Tabel 2. Hasil Uji Beda 3 Populasi

\begin{tabular}{lcccc}
\hline & $\begin{array}{c}\text { Produktivitas } \\
\text { per pohon }\end{array}$ & $\begin{array}{c}\text { Biaya Usahatani } \\
\text { per Pohon (Rp) }\end{array}$ & $\begin{array}{c}\text { Harga Jual Mangga } \\
\text { per kg (Rp) }\end{array}$ & $\begin{array}{c}\text { Penerimaan per } \\
\text { pohon (Rp) }\end{array}$ \\
\hline Rata-rata A & 138,18 & $432.364,93$ & $6.095,38$ & $425.087,00$ \\
Rata-rata B & 151,56 & $524.162,20$ & $6.898,52$ & $565.101,60$ \\
Rata-rata C & 135,77 & $507.957,35$ & $7.846,92$ & $474.831,32$ \\
Nilai $\begin{array}{c}\text { rata } \\
\text { rats }\end{array}$ & 0,49 & 1,42 & $8,32 * * *$ & 1,30 \\
\hline
\end{tabular}

Sumber: data primer, 2014 (diolah)

Ket: $\mathrm{A}=$ Petani yang jumlah pohonnya terbatas; $\mathrm{B}=$ Petani yang jumlah pohonnya cukup; $\mathrm{C}=$ Petani yang jumlah pohonnya banyak. ***Signifikan pada $\alpha=1 \%$

Rata-rata biaya usahatani per pohon pada petani yang jumlah pohonnya terbatas adalah $\mathrm{Rp} 432.365,-$ per pohon, petani yang jumlah pohonnya cukup adalah Rp 524.162,- per pohon dan petani yang jumlah pohonnya banyak adalah $\mathrm{Rp}$ 507.957,- per pohon. Walaupun secara sepintas terlihat adanya perbedaan angka dari ketiga kelompok tersebut, namun berdasarkan hasil uji beda untuk ketiga kelompok tersebut didapakan bahwa tidak terdapat perbedaan yang signifikan untuk rata-rata biaya usahatani per pohon pada ketiga kelompok tersebut. 
Risiko Produksi dan Pemasaran Terhadap Pendapatan Petani Mangga:

Kelompok Mana yang Paling Berisiko

ELLY RASMIKAYATI ${ }^{2}$, LIES SULISTYOWATI, BOBBY RACHMAT SAEFUDIN

Terdapat perbedaan yang signifikan untuk rata-rata harga jual mangga per kilogram pada ketiga kelompok. Ratarata harga jual mangga per kilogram pada petani yang jumlah pohonnya terbatas adalah Rp 6.095,- per kg, petani yang jumlah pohonnya cukup adalah $\mathrm{Rp}$ 6.899,- per kg dan petani yang jumlah pohonnya banyak adalah Rp 7.847,-- per $\mathrm{kg}$. Hal ini mengindikasikan bahwa ratarata harga jual mangga per kilogram pada petani yang jumlah pohonnya terbatas perlu mendapatkan perhatian karena nilainya paling kecil.

Rata-rata penerimaan per pohon pada petani yang jumlah pohonnya terbatas adalah $\mathrm{Rp} 425.087$,- per pohon, petani yang jumlah pohonnya cukup adalah Rp 565.102,-- per pohon dan petani yang jumlah pohonnya banyak adalah $\mathrm{Rp}$ 474.831,- per pohon. Berdasarkan hasil uji beda untuk ketiga kelompok tersebut didapatkan hasil bahwa tidak terdapat perbedaan yang signifikan untuk rata-rata penerimaan per pohon pada ketiga kelompok tersebut.

\section{Perilaku Petani Mangga dalam Menghadapi Risiko Produksi dan Risiko Pemasaran}

Berdasarkan hasil analisis seperti tersaji pada Tabel 3 menunjukkan bahwa perilaku petani mangga yang jumlah pohonnya terbatas dilihat dari rata-rata biaya usahatani per pohon secara signifikan lebih rendah dari kelompok petani lainnya (petani yang jumlah pohonnya cukup dan banyak). Hal ini mengindikasikan bahwa petani mangga yang jumlah pohonnya terbatas kurang berani mengambil risiko produksi dari pada kelompok petani lainnya.

Perilaku petani mangga yang jumlah pohonnya terbatas dilihat dari rata-rata harga jual mangga per kilogram yang secara signifikan lebih rendah dari kelompok petani lainnya. Hal ini mengindikasikan bahwa petani mangga yang jumlah pohonnya terbatas lebih berani mengambil risiko pemasaran dari pada kelompok petani lainnya.

Tabel 3. Hasil Uji Beda 2 Populasi

\begin{tabular}{|c|c|c|c|c|}
\hline & $\begin{array}{l}\text { Produktivitas } \\
\text { per pohon }\end{array}$ & $\begin{array}{l}\text { Biaya Usahatani } \\
\text { per Pohon }(\mathrm{Rp})\end{array}$ & $\begin{array}{l}\text { Harga Jual Mangga } \\
\text { per kg }(\mathrm{Rp})\end{array}$ & $\begin{array}{l}\text { Penerimaan per } \\
\text { pohon }(\mathrm{Rp})\end{array}$ \\
\hline Rata-rata A & 138.18 & 432364.93 & 6095.38 & 425087.00 \\
\hline Rata-rata B & 143.15 & 515527.50 & 7403.87 & 517001.38 \\
\hline Nilai & -0.38 & $-1.69 * *$ & $-3.54 * * *$ & $-1.35^{*}$ \\
\hline
\end{tabular}

Sumber: data primer, 2014 (diolah)

Ket: $\mathrm{A}=$ Petani yang jumlah pohonnya terbatas; $\mathrm{B}=$ Petani yang jumlah pohonnya cukup 
dan banyak. *Signifikan pada $\alpha=10 \%$, **Signifikan pada $\alpha=5 \%$, ***Signifikan pada $\alpha=1 \%$

Perilaku petani mangga yang jumlah pohonnya terbatas tersebut yang kurang berani mengambil risiko produksi dan lebih berani mengambil risiko pemasaran tentunya akan menyebabkan rendahnya penerimaan yang mereka peroleh dari usahatani mangganya. Hal ini terbukti dari hasil analisis bahwa petani mangga yang jumlah pohonnya terbatas dilihat dari rata-rata penerimaan per pohon secara signifikan lebih rendah dari kelompok petani lainnya.

\section{PENUTUP}

Hasil penelitian menunjukkan bahwa faktor-faktor biaya produksi dan pemasaran yang mempengaruhi pendapatan petani mangga adalah biaya bibit mangga, biaya pupuk ZA/KNO, biaya pupuk kandang, biaya pestisida, biaya tetap, biaya tenaga kerja, dan dummy sistem penjualan. Sementara itu, faktor-faktor risiko produksi dan pemasaran yang mempengaruhi pendapatan petani mangga adalah risiko jumlah pohon, risiko biaya pupuk kandang, risiko biaya pestisida dan risiko harga jual mangga. Selain itu, terdapat perbedaan perilaku petani dalam produksi dan pemasaran mangganya jika petani dibagi ke dalam tiga kelompok, berdasarkan jumlah pohon yang dikuasai, yaitu petani yang jumlah pohonnya terbatas, cukup dan banyak. Jika dilihat dari produktivitas per pohon, biaya usahatani per pohon, harga jual mangga per kilogram dan penerimaan petani per pohon, maka terdapat perbedaan yang signifikan untuk rata-rata harga jual mangga per kilogram pada ketiga kelompok tersebut. Fakta selanjutnya, petani yang jumlah pohonnya terbatas dibanding dengan petani dari kelompok lainnya, kurang berani mengambil risiko produksi, tetapi mereka lebih berani mengambil risiko pemasaran. Hal ini menyebabkan petani mangga yang jumlah pohonnya terbatas dilihat dari rata-rata penerimaan per pohon secara signifikan lebih rendah dari kelompok petani lainnya.

\section{DAFTAR PUSTAKA}

Anugrah, Iwan Setiadji. 2009. Mendudukkan Komoditas Mangga Sebagai Unggulan Daerah Dalam Suatu Kebijakan Sistem Agribisnis; Upaya Menyatukan Dukungan Kelembagaan Bagi Eksistensi Petani. PSEK-Bogor.

Ditjen Hortikultura. 2008. Membangun Hortikultura Berdasarkan Enam Pilar Pengembangan. Direktorat 
Risiko Produksi dan Pemasaran Terhadap Pendapatan Petani Mangga:

Kelompok Mana yang Paling Berisiko

ELLY RASMIKAYATI ${ }^{2}$, LIES SULISTYOWATI, BOBBY RACHMAT SAEFUDIN

Jenderal Bina Produksi

Hortikultura. Departemen

Sulistyowati, L. dan E. Rasmikayati.

Pertanian. Jakarta.

2014. Determinant of

Commercialization of Manggo

Ellis, Frank. 2003. Peasant Economics Farmers In West Java. UNPAD.

(Petani Gurem: Rumah Tangga

Usahatani dan Pembangunan

Pertanian). Diterjemahkan oleh

Adi Sutanto, dkk. Bayu Media.

Hartoyo, S.,T. Mizuno, dan S.S.M.

Mugniesyah. 2004. Comparative Analysis Of Farm Management and Risk: Case Study in Two Upland Village,West Java. In: Hayashi, Y.,

S. Manuwoto dan S. Hartono (Eds). Sustainable Agriculture in Rural Indonesia. Yogyakarta: Gadjah Mada University Press.

Natawidjaja et al., 2013. Faktor Sosial Ekonomi yang Mempengaruhi Petani dalam Mengelola Usaha dan Menggunakan Teknologi. Bandung: LPPM-Unpad.

Natawidjaja, J.M. Latican. 2009. Linking Mango Farmers to Dynamic Market Through Transparent margin partnership Model. Changing Agrifood Markets in Southeast Asia: Impact on SmallScale Producers. SEARCA.

Rodjak, Abdul. 2005. Manajemen Usahatani. Bandung: Pustaka Giratuna. 